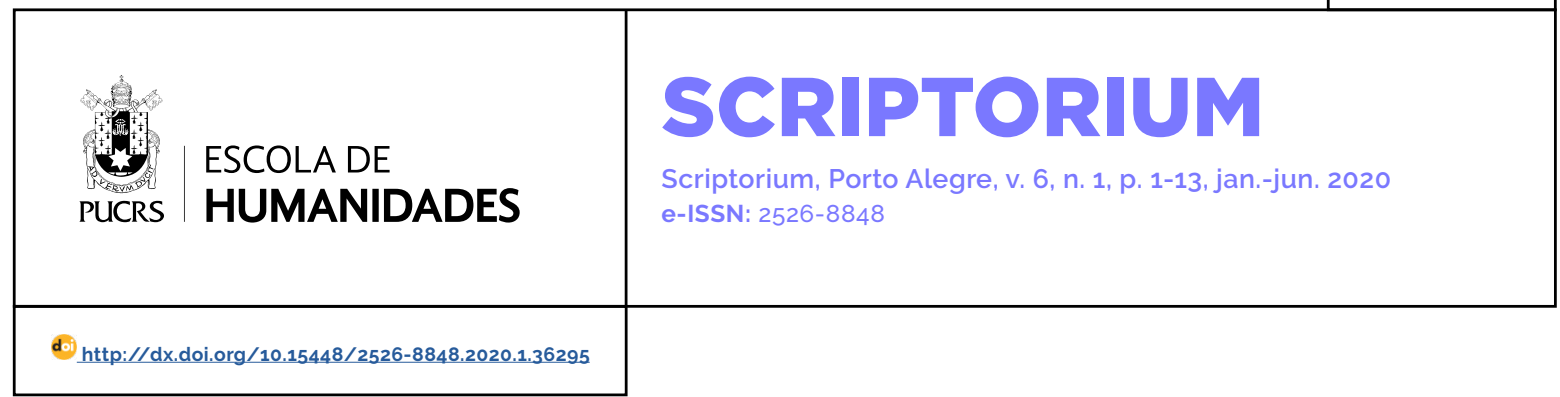

TEMATHIS

\title{
A literatura e a música quando do "fim da canção" em Chico Buarque: uma comparação entre sistemas, tradições e sentidos
}

\author{
Literature and music at the "end of the song" in Chico Buarque: a comparison between \\ systems, traditions and meanings
}

\section{Fernando Cambauva \\ Breda $^{1}$}

orcid.org/0000-0003-1694-1561

fcbreda59@gmail.com

Recebido em: 15 nov. 2019

Aceito em: 21 jan. 2020

Publicado em: 20 jul. 2020
Resumo: Em uma entrevista realizada em 2004, Chico Buarque pontuou uma certa agonia da forma canção no Brasil por conta da emergência do rap no cenário musical. Na visão do artista, menos do que a impossibilidade de se fazer canções, o que estaria em jogo seria o declínio de uma certa forma de sociabilidade brasileira que estaria no seio da formação do sistema cancional brasileiro. É intenção deste trabalho pensar o manejo que Chico Buarque procura mobilizar do sistema cancional brasileiro, bem como as saidas que procura elaborar na literatura. Nesse sentido, o que é posto em discussão são as especificidades que a tradição brasileira da canção ofereceria para lidar com a matéria histórica brasileira quando comparada com as possibilidades oferecidas pelo sistema literário local. Para tanto, procuraremos analisar tais sistemas (e suas respectivas possibilidades) por meio da fortuna critica interessada em debater suas respectivas especificidades históricas, bem como pelas perspectivas que Chico Buarque levantou na entrevista de 2004 e em outros momentos.

Palavras-chave: Sistema literário. Sistema cancional. Teoria Literária. Literatura comparada.

Abstract: In an interview conducted in 2004, Chico Buarque punctuated a certain agony of the song form in Brazil due to the emergence of rap in the music scene. In the artist's view, less than the impossibility of making songs, what would be at stake would be the decline of a certain form of Brazilian sociability that would be within the formation of the Brazilian song system. It is the intention of this work to think about the management that Chico Buarque seeks to mobilize from the Brazilian song system, as well as the outputs that it seeks to elaborate in the literature. In this sense, what is under discussion are the specificities that the Brazilian song tradition would offer to deal with the Brazilian historical matter when compared with the possibilities offered by the local literary system. To this end, we will try to analyze such systems (and their respective possibilities) by crossing part of the critical fortune interested in debating their respective historical specificities, as well as the perspective that Chico Buarque raised in the 2004 interview and at other times. Keywords: Literary system. Song system. Literary theory. Comparative literature.

Em entrevista gravada em 1990 ao documentário Chico ou o país da delicadeza perdida (2003), dirigido por Walter Salles Jr. e Nelson Motta a uma televisão francesa, Chico Buarque levanta que, um dos lastros sociais que estiveram na origem do processo histórico que engendrou a nova canção popular brasileira, era o diálogo entre o "morro" e o "asfalto":

O trabalhador que antes ocupava a zona sul do rio, ele foi sendo expulso Em vez de ser expulso para fora, para periferia, foi expulso pro alto, foi 
ocupar as favelas. E isso criou num primeiro momento um convívio, é claro que sempre houve um contraste social entre a classe média que tá lá embaixo e o morro. Agora, havia, quando ainda não existia um contraste tão violento, havia um convivio que foi, inclusive, responsável pela nova música popular, que é uma estilização da música do morro. Uma música composta pela classe média, com influência marcante da música linterrompe a frase]... Havia-se essa troca de figurinhas entre o pessoal do morro e o pessoal daqui de baixo. Havia o contraste, mas não havia um confronto (BUARQUE, 2003, grifos meus).

Independentemente de sua (im)precisão sociológica, e/ou consideração um tanto exagerada da geografia carioca para a materialização musical do que veio a ser conhecido como a nova música popular brasileira, interessa-nos debater a oposição que Chico faz entre convivio e confronto como condições sócio-históricas que estiveram no seio da formação de determinadas sociabilidades e formas artísticas no Brasil.

Para nos aproximarmos melhor do problema, vale a comparação dessa entrevista com outra realizada pouco mais de uma década depois. ${ }^{2} \mathrm{Se}$ na conversa gravada ao documentário francês, Chico já esboçava uma reflexão sobre um certo esgarçamento do tecido social brasileiro que, pouco a pouco, ia implodindo as condições históricas que possibilitaram o surgimento (e manutenção?) da "nova música popular", a questão toma corpo melhor delineado passado catorze anos.

Quando falou à Folha de São Paulo em dezembro de 2004, o artista, ainda que mobilizando terminologia distinta, propõe uma espécie de radicalização desse ponto de vista. Nesse momento, sugere que a "universalização" do confronto, enquanto mediação social brasileira, como que punha em agonia toda uma forma já consagrada de refletir sobre o Brasil, bem como implodia as bases de elaboração artística e expressiva de uma experiência histórica sentida como convívio - no seu caso específico, fazer canções.
No centro da reflexão do cantor está a discussão sobre a validade e lugar social que a "canção tal como a conhecemos" (termo é do próprio cantor) passava a ocupar no Brasil com o surgimento do rap. Na sua visão, a emergência do rap no cenário cultural brasileiro seria contemporânea e correlata a dois aspectos:

I) a emergência de novos pontos de vista, temas e formas de expressão sobre a experiência histórica contemporânea no Brasil, distantes do que é proposto pela "canção tal como a conhecemos":

O pessoal da periferia se manifestava quase sempre pelas escolas de samba, mas não havia essa temática social muito acentuada, essa quase violência nas letras e na forma que a gente vê no rap. Esse pessoal junta uma multidão. Tem algo aí. (BUARQUE apud BARROS E SILVA, 2004, sem página)

II) perda do lugar social e capacidade imaginativa que a canção ocupava até então:

Talvez tenha razão quem disse que a canção,
como a conhecemos, é um fenômeno próprio
do século passado. [...] A minha geração, que
fez aquelas canções todas, com o tempo só
aprimorou a qualidade da sua música. Mas
o interesse por isso hoje parece pequeno.
Por melhor que seja, por mais aperfeiçoada
que seja, parece que não acrescenta grande
coisa ao que já foi feito. E há quem sustente
isso: como a ópera, a música lírica foi um fenô-
meno do século 19, talvez a canção, tal como
a conhecemos, seja um fenômeno do século
20. No Brasil, isso é nitido. Noel Rosa formatou
essa música nos anos 193O. Ela vigora até os
anos 1950 e aí vem a bossa-nova, que remo-
dela tudo - e pronto [...] Quando você vê um
fenômeno como o rap, isso é de certa forma
uma negação da canção tal como a conhe-
cemos. Talvez seja o sinal mais evidente de
que a canção já foi, passou. (BUARQUE apud
BARROS ESILVA, 2004 , sem página, grifo meu)

Convém assinalar que o que Chico está pondo em questão - menos do que a falsa polêmica sobre a (im)possibilidade de se fazer canções ${ }^{3}$ - é a possibilidade da "canção tal como a conhecemos" atuar como forma e local privilegiados à discussão

Entrevista concedida à Folha de São Paulo no dia 26 de dezembro de 2004. Cf.: BARROS E SILVA, Fernando. O tempo e o artista. Folha de São Paulo, dez. de 2004

3 De resto, rechaçada pelo cantor nesta mesma entrevista: "Estou dizendo tudo isso e pensando ao mesmo tempo que talvez seja uma certa defesa diante do desafio de continuar a compor. (...) Esse pessoal [do rapl junta uma multidão. Tem algo aí. Eu não seria capaz de escrever um rap, e nem acho que deveria. Isso me interessa muito, mas não como artista e criador. O que eu posso é refazer da melhor maneira possivel o que já fiz. Não tenho como romper com isso. E quando penso na melhor maneira possivel, penso imediatamente em Tom Jobim". 
e constituição imaginária da nação. Nesse sentido, é necessário um breve recuo a fim de compreendermos que forma e local são esses que faz referência, ainda que de maneira elíptica e tangencial.

Da perspectiva que adotaremos neste trabalho, o fim da canção que ele procura apontar na entrevista guarda relação direta, é claro, com aspectos formais postos em cenas a partir do rap. Mas, é ainda mais fundamentalmente ligado a uma determinada maneira de pensar o Brasil. Nesta espécie de epistemologia de interpretação nacional, o sentido histórico da nação estaria alicerçado numa narrativa integradora que continha em si a ideia de um convívio harmônico entre diferentes frações sociais e uma projeção virtual de um futuro redentor ao país. É fundamentalmente pela negação dessas ideias de nação que a emergência do rap como que "punha em cheque" o cenário (imaginativo) histórico, social e cultural em que atuava a canção.

Como já assinalou Fernando Barros e Silva (2009, p. 1), tomar o anunciado "fim da canção" ao pé da letra ou como mero artifício retórico da parte de Chico Buarque não nos ajuda a compreender o que está em debate. Quando ele levanta essa "saida de cena" da "canção tal como a conhecemos" em detrimento do rap, está também pondo em evidência uma certa agonia do sistema cancional brasileiro4 (GARCIA, 2013b, p. 15-16), ligado, por sua vez, àquela forma de enxergar o Brasil sedimentada na ideia de encontros sociais harmônicos e de uma integração nacional por se realizar.

Nesse sentido, não é casual que o modelo de canção a que Chico Buarque faz referência nas entrevistas de 1990 e 2004 tem no samba "formatado" por Noel Rosa e na "remodelação" bossa novista seus pilares fundamentais. Aliás, mais do que a ancoragem no samba como um gênero em abstrato, a adoção de uma "linha evolutiva" (para ficar nos termos de Caetano Veloso $)^{5}$ formada por Noel Rosa e João Gilberto como o caminho pelo qual a nova música popular brasileira surge como "origem mítica" é significativa e, no mais, reveladora do sistema cancional a que o autor faz referência, bem como de seus respectivos horizontes históricos.

Conforme estudos de Marcos Napolitano, Francisco Bosco, Walter Garcia e Acuam Oliveira, tal sistema tem seu periodo de formação fundamentalmente ligado a meados da década de 1910 até a década de 1950; coincidindo, portanto, com uma nova visão de país que ia se afigurando no imaginário nacional. No centro dinâmico destas duas formações - de um novo imaginário de país e de um sistema cancional no Brasil - reside os processos de urbanização, de transição da hegemonia das tradições rurais às tradições urbanas e dos esforços para unificação cultural do território brasileiro. ${ }^{6}$

Assim, se tomarmos que a literatura atuou nos séculos XVIII e XIX como espaço de maior relevância à reflexão, imaginação e discussão sobre a vida nacional pensada em unidade7 ${ }^{7}$ com a urbanização acelerada levada a cabo no século

\footnotetext{
4 A utilização da noção de sistema cancional tem, é claro, como filiação metodológica o programa de Antonio Candido para o estudo da literatura brasileira. Em seu clássico livro Formação da literatura brasileira (1959), o crítico literário propõe uma abordagem da literatura nacional a partir da distinção entre sistema e manifestação literária. O que está em jogo na abordagem de Candido é o adensamento histórico, ou não, de uma tradição a que determinados autores se referem e reconhecem a si próprios como integrantes da mesma. Assim, ao não se integrarem neste processo de adensamento de determinada tradição, suas obras literárias como que estariam "fora da literatura", sendo antes manifestação literária (atuando, de certa forma, isoladas). Por outro lado, no entendimento de Candido, o adensamento de uma tradição dependeria da conformação de um sistema triangular em que as obras estejam conectadas por denominadores comuns, no caso: a existência de um conjunto de produtores literários, mais ou menos conscientes do seu papel; um conjunto de receptores, formando os diferentes tipos de público, sem os quais a obra não vive; um mecanismo transmissor, (de modo geral, uma linguagem, traduzida em estilos), que liga uns a outro (CANDIDO, 2000, p. 23). A minha adoção deste mesmo modelo não compartilha de um certo "gozo" pela formação de um sistema literário (ou cancional, que seja); trata-se antes de uma opção metodológica que parece-me apropriada a se pensar a consolidação de determinadas tradições no Brasil

5 Cf. VELOSO, Caetano. Que caminho seguir na Música Popular Brasileira? Revista Civilização brasileira, ano I, n.7, maio 1966

6 Conceitualmente, apoio-me na noção de "comunidade imaginada", tal como formulada por Benedict Anderson. Ou seja, a referência aqui aos esforços de unificação cultural do território brasileiro compreende uma série de políticas que tiveram como horizonte a consolidação de um imaginário de pertencimento a uma mesma comunidade geral de todas as pessoas que ocupavam o território oficial brasileira. Ou ainda, nas palavras de Anderson, na formação de um senso de pertencimento imaginário comum em que "mesmo os membros das mais minúsculas nações jamais conhecerão, encontrarão, ou sequer ouvirão falar da maioria dos seus companheiros, embora todos tenham na mente a imagem viva de comunhão entre eles", partilhando com tais membros desconhecidos, inclusive um certo senso de profunda camaradagem horizontal (ANDERSON, 2008, p. 32-4).

"A literatura foi entre nós uma espécie de matriz, de solo comum, que, por mais tempo que em outros países, alimentou os estudos sobre a sociedade, dando-lhes viabilidade numa cultura intelectualmente pouco diferenciada. Os brasileiros que lidaram até os nossos dias com as ciências do homem fizeram-no em grande parte como escritores - com atitude mental, linguagem, métodos mais adequados à criação literária (no sentido amplo) do que ao objeto de estudo que escolhiam" (CANDIDO, 2006, p. 291).
} 
XX, o surgimento de novos campos culturais vão acabar ganhando preponderância sobre a literatura no que diz respeito à representação e reflexão sobre o país e sobre a brasilidade; dentre estes novos campos destacam-se a canção e o futebol.

Por outro lado, e de forma complementar, o mesmo processo de modernização e urbanização pelo qual passava o país lançava novas bases à própria ideia do que viria a ser aquele "novo país" no concerto das nações... ou ainda, as discussões sobre o "sentido da formação do Brasil" pouco a pouco ia ganhando novos contornos (NOBRE, 2012). A velha ideia colonial de um país por fazer, atrasado em relação ao "sentido geral da história"8, mantinha-se na ordem do dia, com uma diferença significativa: a junção (violenta) de diferentes populações a uma mesma comunidade imaginada, que antes era encarada como empecilho à realização futura do país, invertia-se de sinal. Ascendia, assim, no imaginário social a ideia de que a "força do Brasil" provinha justamente da combinação "bonita e exótica" originária da convivência harmônica, misturada e interpenetrada, entre as variadas culturas e formas de vida locais.

Exemplo maior nesse sentido seria a ideia de mestiçagem: se até então ela era encarada como uma espécie de condição natural que faria do Brasil um país eternamente subalterno, o cenário vai, pouco a pouco, se alterando no sentido dela própria ser alçada como fator de vantagem histórica. Reconhecida como marca da diferença brasileira, ela passa de obstáculo a combustivel de nossa aceleração - é verdade que com um encobrimento profundo de dinâmicas raciais extremamente violentas.

É então nesse novo cenário sociocultural, sobretudo a partir das décadas de 1930 e 1940, que novos símbolos de identidade e brasilidade vão sendo acrescentados ao "inventário" anterior: soma-se assim à imagem do país dotado de natureza exótica, exuberante e tropical, uma população mestiça, cordial e alegre, cuja matriz musical seria o samba. E assim voltamos à formação do sistema cancional.

O samba, portanto, não figura por acaso na "linha evolutiva" da qual fala Chico Buarque na entrevista de 2004: ele seria o gênero musical por excelência do imaginário nacional calcado nas ideias de encontro e convivio, as quais o cantor faz referência na entrevista de 1990. Daí a menção a Noel Rosa: a tal da "formatação" empreendida por Noel na década de 1930 foi um movimento artístico fundamental para a estabilização de uma forma de canção que perduraria até fins da década de 1950... ou até a "remodelação" levada a cabo por João Gilberto.

Nesta formatação empreendia por Noel, o que se estabiliza esteticamente é uma espécie de linguagem cancional que conciliava tanto aspectos da vida dos morros, como da vida do asfalto. Conforme Bosco, "Noel é aquele que define e consolida a forma da canção", afirmando-a como canção popular, isto é, com "linguagem própria, irredutivel à cultura erudita, musical ou literária, linguagem com compromissos de inventividade artística e sucesso comercial, linguagem atrelada ao cotidiano brasileiro, cuja história ela ajudava a contar e a criar" (BOSCO, 2007, p. 53). Assim, nesse modelo estético formatado por Noel, seu lastro histórico é justamente o

$$
\begin{aligned}
& \text { equilibrio entre formas populares tradicionais e } \\
& \text { o ritmo moderno da vida urbana. [...] um gênero } \\
& \text { popular, urbano e industrial que define sua } \\
& \text { identidade pelo trânsito ininterrupto e equi- } \\
& \text { librio malandro entre as técnicas modernas } \\
& \text { de mercado e a tradição reprimida da cultura } \\
& \text { negra (OLIVEIRA, 2015, p. 35). }
\end{aligned}
$$

No mais, os próprios avanços técnicos da indústria fonográfica contribuiam à estabilização, modernização e comercialização das formas populares de se produzir canções. O advento do fonógrafo e do gramofone, além de criar um mercado para canções, por sua própria constituição técnica - vantagem à gravação de canto

\footnotetext{
8 "A discussão que se faz em torno do nacional encontra-se marcada por uma determinada concepção de tempo. Hoje dizemos, sem hesitação, concepção eurocêntrica da história. (...) Ė somente com a Revolução Industrial que a noção de progresso se impõe de fato torna-se dominante, associando-se a valores como liberdade, soberania e democracia. Existe agora um 'sentido da história'. Esta pode ser narrada a partir de um ponto inicial, o estado selvagem, sendo constituída de diferentes etapas no caminho inexorável para a civilização. Um vetor linear do tempo ordena a sucessão dos periodos históricos, ele situa no espaço os povos que se encontram avançados ou atrasados em relação às exigências materiais e espirituais do ideal civilizatório. (...) Se a nação é uma formação social recente torna-se necessário inseri-la no movimento progressivo da história" (ORTIZ, 2013, p. 613).
} 
e/ou acompanhamentos mais simples, uma vez que a sobreposição de muitos instrumentos em simultânea, como na música erudita, gerava resultados bastante precários - acabou por "favorecer" a forma artística produzida na casa das "tias" baianas (Tia Ciata talvez seja a de maior renome), desvinculada da música erudita e com entoação muito próximas da linguagem oral e cotidiana brasileira... Que, por sua vez, estão no âmago do processo produtivo de Noel Rosa, ainda que neste a criação coletiva de canções deixe de figurar como procedimento estético.

De todo modo, a estabilização empreendida pela formatação de Noel pode ser tipificada em três aspectos que acabaram por consolidar-se como constitutivos da forma canção no Brasil:

[I] desenvolvimento de uma linguagem baseada no princípio de estabilização do modo de dizer do português brasileiro em uma forma estética que não perde de vista seu lastro entoativo, meio caminho entre as dimensões prática e artística da linguagem (...)

[II] a não-institucionalização do saber necessário para o domínio dos procedimentos destinados à confecção da canção (...)

[III] o grau de desenvolvimento dos meios de produção da sociedade e o desenvolvimento da indústria fonográfica, responsável pela possibilidade de gravação do registro oral diretamente, sem a necessidade de formas de mediação escritas (OLIVEIRA, 2015, p. 3).

Ora, o ajustamento artístico final resultou numa configuração estética das mais profícuas à consolidação de formas artísticas marcadas pelo encontro e convivio. Os projetos nacionais de conciliação racial e encontros policlassistas passavam a encontrar, então, no samba formatado por Noel Rosa seu correlato semiológico. A forma híbrida, do encontro e mestiça do samba passa a como que confirmar em termos culturais o país como espaço de encontros e misturas, alavancando-as no imaginário como constitutiva e específicas de nossa gente.
A esse primeiro momento de consolidação de uma estética do convivio virá um segundo: a remodelação do samba empreendida por João Gilberto na década de 1950, sobretudo a partir do lançamento de seu álbum Chega de saudade em $1958 .{ }^{9}$

O enorme sucesso deste álbum entre os estratos médios da sociedade brasileira acabou por organizar um novo modelo imaginativo de se produzir canções no país, o qual procurava conciliar em si três aspectos fundamentais: a assunção de uma identidade nacional mais fluida e internacionalizada (consciente, no entanto, de sua própria especificidade local); a projeção histórica de um "encontro do Brasil com o futuro" que se anunciava para "daqui a pouco"; e, finalmente, a elaboração estética no campo cancional calcada na pesquisa de materiais populares e um suposto "refinamento estético, fazendo com que a produção cancional recorra às sonoridades populares sem confundir-se com elas. Na boa formulação de Acauam Oliveira:

O surgimento de João Gilberto marcaria o pon-
to em que a canção brasileira toma consciência
radical de sua especificidade (sua vocação
melódica-entoativa). Por outro lado, tão im-
portante quanto esse aspecto de continuidade
coma "matriz constitutiva" da canção brasileira
é sua diferença com relação a ela, posto que
inaugura uma postura inédita frente à canção,
tomada agora como resultado de um trabalho
intelectual crítico, exibida ao público em seu
processo de confecção. (...) Enquanto o samba
instaura o paradigma conciliatório na canção, o
projeto estético politico de dar forma à fluidez
e ausência de caráter "constitutiva" da socieda-
de brasileira, a bossa nova faz desse paradigma
o ponto de partida da nossa modernização,
cujas contradições serão vividas e disputadas
intensamente pela MPB (OLIVEIRA, 2015, p. 30).

Assim, nesta remodelagem levada a cabo por João Gilberto (para ficarmos nos termos do próprio Chico Buarque), a canção passava a ocupar um lugar de prestígio e relevância que não ocupava até então. Ela não só passava a dinamizar um mercado interno de canções ${ }^{10}$, como passava a oferecer uma

\footnotetext{
9 Apesar da inegável importância seminal de trabalhos como o álbum Chega de Saudade, de João Gilberto, é preciso ter cuidado com a ideia de que a Bossa Nova foi o "grau zero" da história musical brasileira. (...) Nem a Bossa Nova apagou do cenário musical o Samba tradicional e o Samba canção bolerizado, comercialmente fortes nos anos 50, nem se constituiu sem dialogar com estes estilos (...) A Bossa Nova foi o filtro pelo qual antigos paradigmas de composição e interpretação foram assimilados pelo mercado musical renovado dos anos 60 (NAPOLITANO, 2001, p.70).

10 Em 1959, de cada 10 títulos comprados, 7 eram estrangeiros. Em 1969, essa relação se inverte nas mesmas proporções. Havia um nítido processo de substituição das importações em curso: o mercado brasileiro passou a consumir canções compostas, interpretadas e produzidas, na forma de fonogramas, no próprio país (NAPOLITANO, 2001, p.62-3)
} 
imagem moderna do Brasil ao mundo ${ }^{11}$ e, sobretudo, alçava-se ao centro da reflexão pública e coletiva sobre a nação, seu imaginário e seu futuro.

Mais do que meras formas de produção artísticas, tanto o samba quanto a Bossa Nova carregam em si uma vinculação formal, simbólica e histórica com uma estrutura de sentimento ${ }^{12}$ (WILLIAMS, 1979) das mais importantes do século $X X$ brasileiro. Aquém ou além de gêneros musicais e/ou procedimentos técnicos de produção cancional, tanto o samba, como a Bossa Nova (e a própria MPB) estão ancorados num sentimento compartilhado e um tanto quanto difuso de que, pautado em suas supostas marcas diferenciais, um dia o "Brasil daria certo"13: o convívio cordial e harmônico entre frações sociais articulado a um regime racial mais democrático fariam da vida local uma espécie de promessa social de uma "utopia cordial brasileira". ${ }^{14}$

Não por acaso, a década de 1950 como que inaugurava um novo ciclo de otimismo modernizante (modernista?) na vida ideológica brasileira, que parecia coincidir com a utopia cordial da Bossa Nova: as próprias circunstâncias históricas como que forjavam uma nova narrativa política, econômica e cultural que parecia confirmar a expectativa de que finalmente o Brasil encontraria o caminho das pedras (pulando etapas, inclusive) para alçar-se a sócio/ protagonista - ou global player, para ficarmos na terminologia mais moderna - do capitalismo mundial. A consolidação de uma indústria nacional, o crescimento do mercado interno, o interesse internacional pela produção cultural local, a construção de Brasilia, a conquista da Copa do Mundo em 1958 e 1962, dentre outros fatores, constituíam toda uma série de elementos econômicos, políticos e culturais que faziam com que figurasse aos brasileiros - e também ao mundo - de que a hora do país "estava chegando". ${ }^{15}$

Conforme espero ter ficado claro até aqui, o ponto de vista de Chico (2004) é, portanto, de quem viu uma espécie de aposta histórica de um salto civilizador brasileiro - ao mesmo tempo modernizante e cordial - ter se diluido num tempo histórico em que a sensibilidade artística do cantor parece ver mais desagregação do que propriamente a elaboração coletiva de uma narrativa nacional comum.

Ainda acompanhando o raciocínio de Chico Buarque, seria na formulação estética do rap que a experiência histórica brasileira contemporânea ganharia melhor corpo... ou ainda, "tem algo ai". O que seria, afinal das contas, esse tal sentido contemporâneo que Chico vê na forma do rap?

Se é verdade que as formas cancionais brasileiras do século XX, de modo geral, se realizaram a partir do paradigma da formação de um país novo cuja mestiçagem e intercâmbio cultural local teriam uma

\footnotetext{
11 O show no Carnegie Hall em 21 de novembro de 1962, em que a Bossa Nova foi a atração principal de um evento, acabou se transformando num marco do sucesso e disseminação internacional do movimento. João Gilberto posteriormente gravaria com Stan Getz e Tom Jobim com Frank Sinatra.

12 Faço referência ao conceito "estrutura de sentimento" proposto pelo crítico cultural inglês Raymond Williams (1979, p.34). Em sua conceituação a respeito, propõe a existência de operadores sociais etéreos e difusos como um sentimento que, ao mesmo tempo, tem a força determinante de uma estrutura.

${ }_{13}$ Segue trecho de depoimento de Paulo Arantes comentando sobre sua formação intelectual no período e o imaginário de país que estava armado: "Voltemos a minha formação, quer dizer, a formação dos meus maiores, revista agora por esse prisma inusitado. Espero não estar armando um falso problema, mas pensando bem, nada mais 'careta' do que a obrigação, herdada de uma longa tradição construtiva, de encontrar uma 'saida' para o Brasil, tirar nosso 'atraso' relativo, mesmo quando repensado em termos de formas produtivas e relações sociais de produção, afinal era preciso 'dar certo' como dera certo o capitalismo nos países 'avançados'" (ARANTES, 2016).

${ }_{14}$ A ideia de uma utopia cordial brasileira é de Walter Garcia, apoiado na leitura que faz de Lorenzo Memmi. Acompanhando o que o último propõe a bossa nova como que emularia "uma sensação de temporalidade suspensa que não é ócio, mas uma atividade que se produz naturalmente, sem sofrimento ou esforço, como por emanação" (MEMMI, 1992, p. 70); assim, ela conteria em si um projeto utópico de um tempo histórico absolutamente moderno e racional, que, no entanto, não se desvincularia do que haveria de mais específico na vida social brasileira: essa aproximação emotiva da vida pública (trabalho ai incluído). Em termos estéticos, essa estranha combinação contraditória entre uma expectativa num futuro moderno e a recusa em aceitar aquilo que se perderia na transição ao novo, é sentida na tensão entre o amadorismo e a perfeição técnica que marcavam os shows dos grandes artistas bossa-nova. "A intimidade tão exibida dos shows de bossa nova, o excesso de apelidos carinhosos (Tonzinho, Joãozinho, Poetinha), [...] esta necessidade contínua de confirmações afetivas" (MEMMI, 1992, p. 64) conviviam sem alarde com exigências técnicas das mais precisas por parte desses mesmos sujeitos, que não exibiam o menor puder em se chamarem publicamente por apelidos carinhosos.

15 É possivel que não seja da menor importância ressaltar que este sentimento chegou mesmo a ser compartilhada por setores da esquerda. No campo da canção, por exemplo, a radicalização política experienciada nos anos 1950 e 1960 foi correlata a uma radicalização dos procedimentos técnicos e de pesquisa bossa novísticos. Ȧ noção de uma produção estética amparada na pesquisa de fontes populares somou-se a ideia de um complexo engajamento combinado entre movimentos pela consolidação de um mercado fonográfico nacional e tentativas de mobilização das massas à construção da revolução brasileira. A esse grupo de artistas e movimentos foi dado o rótulo ou seja, um termo cuja "definição se dava mais pelo lugar social do que pela sua coerência estética" (NAPOLITANO, 2001, p. 229) - de MPB.
} 
força emancipadora para a civilização do resto do mundo, não foi deste ponto de vista, nem mesmo desta tradição estética que partiu a obra dos Racionais MC's - grupo paulistano que tomaremos aqui, junto com outros autores como D'Andrea e Oliveira como uma espécie de tipo lukacsiano desta nova tradição que ajudaram a construir.

Simplificando bastante a questão, o surgimento do grupo é tributário de uma tradição estética nova e inovadora que, na falta de elementos na cultura brasileira "clássica", teve que recorrer a um modelo artístico estrangeiro, o rap, e às discussões raciais levadas a cabo nos Estados Unidos, para compor um novo projeto estético-ideológico de mundo, sem, no entanto, deixar de se vincular diretamente à vida local. ${ }^{16}$

Grosso modo, acompanhando as proposições de Acauam Oliveira e Tiaraju D'Andrea, o lastro histórico que possibilitou a formação de um grupo como os Racionais MC's foi a chamada "formação dos sujeitos periféricos" (D'ANDREA, 2013). ${ }^{17}$ Assim, é importante ter em mente que este processo seria resultante, dentre outras coisas, da articulação histórica da conjuntura dos anos 1990, quando a ofensiva neoliberal no Brasil se deu em simultâneo ao enfraquecimento do movimento operário e à guinada "pragmática" da maior ferramenta de luta dos trabalhadores à época, o Partido dos Trabalhadores. Além disso, a concentração de renda e desigualdade social aumentavam na esteira da financeirização da economia nacional, resultando numa favelização crescente e no florescimento de uma lógica de segurança pública pautada no punitivismo do Estado e nos condomínios fechados (ou enclaves fortificados) da vida privada.

Neste contexto, não bastasse o recuo das forças populares, a fragilização de conquistas sociais e o mundo do trabalho se deteriorando consideravelmente, as periferias da cidade de São Paulo experienciavam um boom de violência. Foi esse o cenário desolador, então, que forjou essa nova subjetividade histórica:

\begin{abstract}
Desesperançada, pobre, desempregada e absorvida nas matanças corriqueiras de jovens entre si e destes com a polícia, a população periférica empenhou-se em construir mecanismos e inventar formas para contornar a violência e se manter viva. (...) Em torno dessas situações e dessas experiências, a população periférica engendrou uma narrativa e elaborou uma subjetividade para explicar seu lugar no mundo e fundamentar sua existência. Por outro lado, surgiu uma nova subjetividade por meio de uma intensa luta para se colocar no mundo e se perceber por meio do orgulho, e não do estigma (D'ANDREA, 2013).
\end{abstract}

Os resultados foram em várias ordens e sentidos. No entanto, conforme aponta a tese de D'Andrea, foi a obra dos Racionais MC's que melhor expressou essa nova subjetividade emergente.

Do ponto de vista formal, a obra do Racionais forja também um novo modelo de produção artística no e do Brasil. A noção básica em que o rompimento se assenta é o abandono do movimento de constituição imaginária da nação por meio da cultura.

Em seu lugar se põe um movimento em sentido contrário, a contrapelo, constituindo-se a partir das ruinas de um projeto de país, comprometendo-se ética e formalmente justamente com aqueles que foram postos à margem de uma integração nunca realizada. Resultando deste outro ponto de vista, o dos "sujeitos periféricos", uma subversão significativa de padrões estéticos que modularam boa parte da tradição cultural brasileira.

Ao invés da tradição melódicolentoativa, (forjada desde o início do século, e cujo "laboratório" privilegiado foi o samba), que pressupõe certo

\footnotetext{
16 É interessante observar que mesmo a mobilização de grandes nomes da MPB, como Jorge Ben Jor e Tim Maia, é recuperada numa chave voltada à negritude; ou seja, em chave distinta da que Caetano Veloso mobiliza, por exemplo, ao cantar Jorge Ben Jor: "Pela própria associação estreita entre essas temáticas, que compõem uma matriz estética internamente coerente, verifica-se que a abordagem das letras sobre o 'mundo do crime' de morros e favelas está em descompasso flagrante com a tradição de esquerda do periodo, majoritariamente vinculada a setores 'subversivos' de matriz intelectual marxista e, quando muito, a grupos mobilizados de operários e católicos vinculados à teologia da libertação. Não é desses setores populares engajados na luta política contra a ditadura, em cujos discursos 'trabalhador e bandido' compõem um par moral de opostos, que emana a narrativa de Jorge Ben. Na medida em que a censura estatal preocupava-se sobretudo com esta esquerda, e com seus principais porta-vozes na música e nas artes, o trabalho de Ben foi lido mais como entretenimento do que como pensamento critico, mais associado à festa do que a qualquer forma de ação politica. O mesmo aconteceu com Tim Maia, que não por acaso será igualmente cultuado pelo rap paulista como um dos pais fundadores da 'tradição de música black brasileira', influência marcante de figuras como Cassiano, Simonal e Gerson King Combo" (FELTRAN, 2013, p. 49).

17 Ainda que a referida formação diga respeito a processos vividos nas periferias da cidade de São Paulo, no âmbito da cultura o impacto dos Racionais é de dimensão nacional.
} 
equilibrio de opostos (melodia e entoação), investe-se em um modelo radicalmente entoativo que afirma a irredutibilidade da voz do jovem negro da periferia, que não se presta a universalização da experiência nacional. Ao invés de um ponto de vista lírico de enunciação, calcado na crônica do cotidiano, um modelo épico que faz da multiplicidade das vozes dos cinquenta mil manos o seu ponto de força. Ao invés de apostar na dialética da malandragem e na tradição dos encontros culturais, a aposta na ruptura e na diferença radical entre classes e raça, entendendo a sociedade brasileira como campo de conflito radical (OLIVEIRA, 2015).

Ora, voltando à questão levantada por Chico, a partir do que propõe o cantor, o rap seria, portanto, ao mesmo tempo, capaz de expressar uma radicalização do confronto e da violência social brasileira, ao mesmo tempo que punha em cena formas e temas de expressão de uma parcela populacional que não se via representada nas imagens de Brasil formuladas pela canção tal como a conhecemos. ${ }^{18}$

A canção tal como não a conhecemos parecia mais próxima da experiência histórica contemporânea no país do que aquela formulada pela geração de Chico. A percepção de uma mudança radical de tempos históricos foi sentida pelo cantor. Sua saída? A literatura e, na canção, a assunção radical de seu lugar social no confronto universalizado da vida brasileira. ${ }^{19}$

Não cabe neste artigo expor uma análise minuciosa de procedimentos técnicos e sentidos históricos que estão expressos em suas obras, seja na literatura, seja na canção. No entanto, como a discussão que pretendemos fazer demandam uma demonstração das mesmas, fica já exposto que tomaremos como base análises e interpretações das obras de Chico Buarque feitas por Acauam Oliveira, Roberto Schwarz, Marcelo Ridenti, Edu Otsuka e Walter Garcia. A despeito de não apresentarem congruência total entre si, tais autores compartilham da interpretação de que na obra literária de Chico existe uma radicalidade quanto à inviabilidade da formação social brasileira - ou ainda daquele salto civilizatório de que falamos anteriormente - que não encontra expressividade em sua produção musical.

Seguindo os rumos apontados pela crítica, especialmente por Walter Garcia, o bloqueio formal de Chico Buarque na canção seria tributário de uma espécie de "impossibilidade" que ele se depara para mimetizar a violência e esgarçamento social contemporâneo. Se o que viemos discutindo até aqui estiver correto, a crise formal que o cantor enfrenta no tratamento estético da violência e segregação urbana, por exemplo, ganha tratamento formal distinto nos romances. Como se essa distinção entre tratamentos, ela própria, fosse marca justamente de uma certa tentativa de superação pelo escritor da agonia formal que o cantor enfrenta. Ou como se no tratamento da matéria histórica, a canção encontrasse limites que a literatura não enfrenta.

Uma breve comparação entre duas circularidades expressas por Chico-escritor e por Chico-cantor pode nos ajudar a compreender os impasses de que estamos falando, a saber: a encontrada em Estorvo, cuja movimentação agônica psico-histórica se dá na forma e a partir da mesma; e a da canção "Subúrbio", em que a própria forma é que parece estar em agonia. A circularidade do tempo e da narrativa parecem encontrar e não encontrar, respectivamente, saidas formais à sua própria expressão. ${ }^{20}$

\footnotetext{
18 Conforme levantou a psicanalista Maria Rita Kehl, eles foram capazes "de forçar a barra para que a cara deles seja definitivamente incluída no retrato atual do país (um retrato que ainda se pretende doce, gentil, miscigenado)" (KEHL, p. 97, 1999).

19 Em entrevista concedida à Revista Ocas, a contraposição que o próprio cantor faz do espaço de sua moradia com o mirante é significativo da consciência de Chico quanto a seu lugar social, sem apelos demagógicos: "Mas o que acontece hoje é que você vive com esse clima, e o que te ameaça não vem do inimigo. Esses caras que estão fazendo isso, eu provavelmente dou razão a eles. Se o cara quiser entrar aqui em casa e levar essa porra toda, me dar porrada, eu vou ficar muito puto, não vou gostar de apanhar, mas no fim das contas vou pensar que se eu estivesse no lugar dele faria a mesma coisa. As vezes as pessoas jogam pedras do mirante aqui na minha piscina, e eu penso que, se eu estivesse lá em cima, também jogaria, entende? Estou lá, vendo isso tudo aqui embaixo, estou sem um puto, eu não vou virar evangélico, não vou ler a Biblia, talvez tente trabalhar e não consiga nada e, aí ainda mais, eu vou querer aquela bicicleta daquela garota que está passeando na Lagoa" (BUARQUE, 2004a, sem página).

20 Cabe assinalar que a escolha de "Subúrbio" e Estorvo não foi por mera coincidência e/ou congruência interpretativa. A despeito de dois momentos distintos da carreira do artista, elas dialogam diretamente com as entrevistas de Chico mencionadas neste trabalho. Trocando em miúdos, nelas, ele acaba por trabalhar artisticamente de modo direto com as questões que colocou na entrevista ao documentário e na entrevista à Folha de São Paulo. No mais, o esgarçamento progressivo do tecido social brasileiro que o cantor menciona como que toma o centro da elaboração artística dessas obras, ou seja, mais do que mero tema a ser representado, passa a atuar como principio estético, com suas respectivas expressividades formais.
} 
Em Estorvo, cujo enredo está centrado na figura de seu narrador-protagonista, a estória se inicia em media res: o narrador é desperto de seu sono por um homem desconhecido que bate à sua porta, dando inicio a uma eterna fuga que passa a se constituir como o eixo de movimentação pela qual o livro caminha. Não se sabe ao certo se esse narrador de uma classe média alta, decadente e carioca foge de si ou desse (ou ainda algum) outro qualquer.

A fuga se dá muito provavelmente pela cidade do Rio de Janeiro e arredores, ainda que a mesma não seja propriamente nomeada ao longo do romance. Todavia, as referências geográficas levam a crer que se trata da "Cidade Maravilhosa", figurada, todavia, no romance, muito longe de um olhar maravilhado para com a mesma. O cenário e seus habitantes estão marcados pela catástrofe social: criminalidade, enclaves fortificados, violência espetacularizada, violência real... conformando um verdadeiro cenário de anomia social.

Nessa peregrinação errática do narrador, não só o cenário social se constrói pela negatividade, como constitui-se também por meio uma espiral de fracassos que se acumula indefinidamente e sem nenhuma concessão (Otsuka, 2001). A sucessão de fracassos é, em boa medida, uma espécie de sequências narrativas de choques de temporalidades experienciadas pelo narrador, em que presente e passado se cruzam e se contradizem sem apontar para nenhuma sintese. Assim, a tensão que resulta destes encontros parece nunca apontar para qualquer resolução, resultando numa dupla acepção do tempo: a de um passado nostálgico (?) - que não deixa, entretanto, de mostrar as desigualdades que ali existiam e não se superaram -; e um presente que não vislumbra qualquer possibilidade de redenção.

Como notou o crítico Roberto Schwarz, é como se estivéssemos diante de um cenário de descrenças que se acumulam sem nunca terminar. As velhas possibilidades utópicas, que tanto animaram o imaginário artístico e social brasileiro, parecem cair uma a uma no andamento roma- nesco de Estorvo. O tempo histórico expresso no romance já não aponta a nenhuma crença em qualquer esforço civilizatório em que todos, ricos e pobres, se afundaram em "um atoleiro de que ninguém quer sair e em que todos se dão mal" (Schwarz, 1999). O horizonte histórico não poderia ser mais rebaixado.

Em "Subúrbio", o ponto de vista da canção também se dá a partir de uma voz de algum integrante de uma classe dotada de privilégios, o que se expressa por sua não-identificação com o espaço que dá título à canção: quem canta, fala daqui sobre "lá". No entanto, diferentemente do narrador de Estorvo, sua melancolia para com a vida "daquela gente toda" expressa um certo paternalismo ilustrado, que mesmo em seus momentos de vontade de transgressão progressista (quando, por exemplo, quer que fale, que leve para fora de si sua cultura $)^{21}$ denota uma superioridade de quem fala e é ouvido, frente a uma população que também fala, mas pouco se escutaria. De modo que nesse emaranhado de má consciência e piedade (ou é só mera coincidência a primeira enumeração de bairros suburbanos do cenário carioca encerrar justamente com Piedade?), ainda que o objeto a ser tematizado seja justamente a violência segregadora que desenha o Rio de Janeiro, é como se essa mesma violência não encontrasse na forma expressiva do cantor o mesmo vigor daquilo que é narrado. $O$ clamor do cantor para que essa população (que "não figura no mapa") fale parece ser coabitante e reflexo dessa má consciência, entre a piedade e a autocomiseração diante de um cenário que não parece apontar alguma mudança.

Nesse ponto, a "fala" do cantor seria em alguma medida a própria assunção, na forma, do "fim da canção" mencionado anteriormente: é como se o próprio Eu lírico assumisse sua incapacidade de fazer esse Outro falar e se percebesse num limite, em que falar pelo Outro já é impossibilidade, ao mesmo tempo em que é consciente que a fala desse Outro dificilmente seria escutada. Frente ao

21 "Vai, faz ouvir os acordes do choro-canção / Traz as cabrochas e a roda de samba / Dança teu funk, o rock, forró, pagode, reggae / Teu hip-hop / Fala na língua do rap / Desbanca a outra / A tal que abusa / De ser tão maravilhosa" (CHICO BUARQUE, 2006). 
impasse, ele anda em roda, é fim de linha, é foda. ${ }^{22}$

Se na literatura, a inviabilidade da integração cidadã "daquela gente" encontra uma certa estabilidade formal na voz que narra - mesmo que pela negatividade radical -, na canção o Eu lírico fica a se debater com as formas de narrar fracassos e violências: como dizer o que não ganha forma?

Pensando no projeto que deu lastro à formação do sistema cancional, é como se seu horizonte integratório e harmônico ainda fosse vislumbrado, mas a percepção de sua derrota fizesse confusão na cabeça do Eu lírico. A forma do convívio gira em roda por não conseguir chegar perto de seu Outro?

E aqui chegamos a um ponto importante de reflexão sobre as tradições artísticas brasileiras sedimentadas em diferentes sistemas, no caso, o da canção e o da literatura. Resumidamente, a pergunta que fica é: a despeito de estarem vinculados a uma mesma nação, as tradições sedimentadas no sistema literário brasileiro oferecem possibilidades distintas ao tratamento da matéria histórica local quando comparadas às possibilidades de elaboração artística do sistema cancional? A se avaliar por uma comparação entre a elaboração da música e da literatura de Chico Buarque, a resposta parece ser afirmativa.

É como se na canção a agonia de um projeto de nação - que teria dado lastro à formação de ambos os sistemas - se expressasse com dificuldade no plano da forma ${ }^{23}$, ao passo que na literatura ela consegue estruturar-se como princípio de elaboração estética. Ou ainda, como se na canção, Chico não conseguisse estilizar o esgarçamento social contemporâneo com a mesma radicalidade expressa na literatura.

Estaríamos, portanto, diante de um impasse histórico dessa tradição cancional, sedimentada na ideia de uma utopia vindoura, lastreada, por sua vez, numa antiga (?) sensação de sociabilidades marcadas pelo encontro e convívio cordial das raças e classes. Seria o sucesso da formação de nosso sistema cancional, pautado exatamente nas possibilidades efetivas dessa realização utópica ${ }^{24}$, justamente sua fratura contemporânea, uma vez que a distância entre a utopia e a realidade é gritante?

Passando ao ponto de vista da literatura brasileira, sua formação historicamente fraturada estaria hoje a converter-se em sinal positivo justamente por propiciar recursos expressivo a uma estilização formal não-agônica do esgarçamento contemporâneo? Trocando em miúdos, o sistema literário, que já se forma em fratura, teria sedimentado uma tradição "acostumada" a tratar do esgarçamento social, por sua própria constituição interna?

Se no começo deste ensaio procuramos pensar a formação do sistema de canções, tentaremos encerrá-lo por meio da comparação dessa formação com outra: a do sistema literário. Neste último, seu momento decisivo mais fundamental teria se dado na obra de Machado de Assis, quando a especificidade brasileira é assimilada e, ao mesmo tempo, posta em diálogo com as formas expressivas da literatura mais reconhecida mundialmente, no caso a europeia. ${ }^{25}$

Ocorreria, no entanto, que neste mesmo ponto máximo de formação da literatura brasileira, o romance maduro de Machado de Assis, haveria um impasse formal da maior importância, tal como já observou José Antonio Pasta Júnior. Isto é, se o cerne do romance oitocentista europeu (modelo para Machado) seria a aventura burguesa de um herói, fundamentada, por sua vez, na autorrealização individual, o próprio fundamento romanesco básico sai de cena: a movência das

\footnotetext{
22 A combinação estilistica entre "roda" e "foda" faz ecoar "Diário de um detento" dos Racionais MC's; como bem recorda Walter Garcia, "pode ter sido mera coincidência, mas não deixa de ser interessante". No mais, ainda seguindo Garcia, ela pode fazer referência também à canção "Águas de março", numa espécie de estilização sobreposta em que fica embaçado o que é contraste e o que é confronte de formas. 23 De alguma maneira, a situação faz lembrar as mesmas questões que Rodrigo Naves se deparou analisando alguns artistas plásticos brasileiros: "Essas obras tímidas supõem um modo suave de moldar as coisas, e estão mais para um artesanato amoroso ou para um extrativismo rústico do que para a conformação taxativa da indústria. Contudo, esse ideal meigo que defendem conspira contra suas expectativas, já que essas aparências amenas e essas formas frágeis não podem se opor à opressão do real, que os coage sem cessar" (NAVES, 2011, p. 27)

24 Ao contrário da literatura, não só o sistema cancional se massificou, como por sua própria constituição técnico-produtiva, a inserção popular tem uma margem muito maior do que no sistema literário. Não custa nada lembrar que ainda hoje, a ascensão de um escritor como Geovani Martins toma ares de excepcionalidade por conta de sua origem social.

25 Toda essa discussão em torno da formação de um sistema literário está ancorada nas pesquisas levadas a cabo por Antonio Candido e Roberto Schwarz.
} 
personagens em seus romances maduros nem procura o dinheiro, nem tem como horizonte uma individuação autônoma. Pelo contrário, como narradores membros de uma elite abastada e escravocrata, a noção de trabalho e/ou autorrealização por meio deste não é parte constitutiva de suas formas de vida, senão como ornamento.

Não bastasse isso, a própria voz narrativa de seus romances maduros já seriam índice de uma formação fraturada, ou para ficarmos nos termos de Pasta Jr., uma "formação em ruína", ou ainda, em "formação negativa em evidência de sua própria impossibilidade" (PASTA, 2011). Tomemos o caso das Memórias póstumas de Brás Cubas, narradas pelo defunto autor: a voz que toma para si a narrativa da própria vida não chega a formar-se na medida em que é no próprio nascimento de Brás como narrador que ele morre; ou ainda, é um narrador que nasce morrendo. Poderíamos considerá-lo, portanto, do ponto de vista que se quer uma subjetividade burguesa "clássica", uma espécie de romance natimorto - o que se trata de um mérito da parte do autor. É como se a prosa machadiana desse a "forma clara à degradação causada à vida pelo funcionamento incompleto do padrão burguês no país" (SCHWARZ, 2000, p.144).

Ora, partindo dessa "marca de nascença" de conformação do sistema literário nacional, poderíamos pensá-lo quase como sendo desde o princípio um repositório de nosso fracasso em formar-se enquanto nação integrada e moderna? ${ }^{26}$ No mais, sua própria constituição vinculada às elites, deixando de fora boa parte da população de seu circuito, não seria também uma espécie de travejamento em que o próprio sistema forma-se já deformado? ${ }^{27}$ Nestas condições, a sedimentação de uma tradição literária nacional não tenderia, por si só, a apontar menos para as possibilidades utópicas de integração nacional do que ao próprio naufrágio desta hipótese?

O andar de roda em "Subúrbio" seria o andar de roda em plano formal que o narrador de Estorvo (e mesmo o tempo histórico engendrado no ro- mance) experiência "em vida"? A agonia histórica expressa em Estorvo como que encontraria correlação semiológica na agonia formal (histórica também, é claro) do Eu lírico de "Subúrbio". O problema é semelhante, as formas de expressão é que se distanciam.

\section{REFERÊNCIAS}

ANDERSON, Benedict. Comunidades imaginadas. São Paulo: Companhia das Letras, 2008.

ARANTES, Paulo. Sentimento da Dialética. Rio de Janeiro: Paz e Terra, 1992

ARANTES, Paulo. Sentidos da formação. Rio de Janeiro: Paz e Terra, 1997

ARANTES, Paulo. A fratura brasileira do mundo. In: ARANTES, Paulo. Zero à esquerda. São Paulo: Conrad Editora do Brasil, 2004, p. 25-79.

ARANTES, Paulo. Da noite para o dia. In: COLETIVO DAR (org.). Dichavando o Poder. São Paulo: Autonomia literária, 2016, p. 137-165.

ENTREVISTA com Paulo Eduardo ARANTES. Trans/ Form/Ação, Marilia, v. 31, n. 2, p. 7-18, 2008. https://doi. org/10.1590/S0101-31732008000200001.

BARROS E SILVA, Fernando. Folha explica: Chico Buarque. São Paulo: Publifolha, 2004a.

BARROS E SILVA, Fernando. O tempo e o artista. Folha de São Paulo [online], dez. 2004b. Disponivel em: https:// www1.folha.uol.com.br/fsp/ilustrad/fq2612200408. htm. Acesso em 10 nov. 2019.

BARROS E SILVA, Fernando. O fim da canção (em torno do último Chico). Serrote, São Paulo, v. 3, 2009.

BENJAMIN, Walter. Magia e técnica, arte e politica. São Paulo: Brasiliense, 2010

BOSCO, Francisco. Cinema-canção. In: NESTROVSKI, Arthur (org.). Lendo música. São Paulo: Publifolha, 2007. p. $41-89$

BUARQUE, Chico. 2003. Chico ou o pais da delicadeza perdida. [p1990]. Direção Walter Salles Jr. e Nelson Motta. BMG, 82876538929 .

BUARQUE, Chico. Estorvo. São Paulo: Companhia das Letras, 1995a.

BUARQUE, Chico. Benjamin. São Paulo: Companhia das Letras, 1995b.

BUARQUE, Chico. O tempo e o artista. Folha de São Paulo, dez. De 2004.

26 Cumpre salientar que não se trata aqui de uma defesa velada de um suposto modelo de modernidade, diga-se também europeia ao Brasil. Trata-se apenas de tomar em conta o fato de que os projetos utópicos que deram lastro à formação dos sistemas literários e cancionais estiveram em boa medida baseados no modelo europeu "de sociedade relativamente integrada" (ARANTES, 1997, p. 12).

27 O que, como vimos, não é o caso do sistema cancional, alicerçado em alguma medida justamente em sua inserção popular. 
BUARQUE, Chico. Já estou pegando o violão. Revista Ocas, [s. l.] 24 jul. 2004a. Disponivel em: http://chicobuarque.com.br/texto/mestre.asp?pg=entrevistas/ entre_ocas_240704.htm. Acesso em 30 jul. 2019.

CANDIDO, Antonio. Formação da literatura brasileira. Belo Horizonte: Editora Itatiaia, 2000.

CANDIDO, Antonio. A sociologia no Brasil. Tempo social, São Paulo, v. 18, n. 1, p. 271-301, jun. 2006. https://doi. org/10.1590/S0103-20702006000100015.

D'ANDREA, Tiaraju Pablo. A formação dos sujeitos periféricos. São Paulo: Programa de Pós-Graduação em Sociologia, USP, 2013.

FELTRAN, Gabriel de Santis. Sobre anjos e irmãos: cinquenta anos de expressão política do "crime" numa tradição musical das periferias. Revista do Instituto de Estudos Brasileiros, [s. l.], n. 56, p. 43-72, jun. 2013. https://doi.org/10.11606/issn.2316-901X.voi56p43-72.

FERRÉZ (org.). Literatura marginal: talentos da escrita periférica. Rio de Janeiro: Agir, 2005.

GARCIA, Walter. Diário de um detento: uma interpretação. In: NESTROVSKI, Arthur (org.). Lendo música. São Paulo: Publifolha, 2007. p. 179-216.

GARCIA, Walter. Radicalismos à brasileira. Celeuma, v. 1. n. 1, p. 21-31, maio 2013a. https://doi.org/10.11606/ issn.2318-7875.v1i1p20-31.

GARCIA, Walter. Melancolias, mercadorias: Dorival Caym$\mathrm{mi}$, Chico Buarque, o pregão de rua e a canção popular-comercial no Brasil. São Paulo: Ateliê Editorial, 2013b.

KEHL, Maria Rita. Radicais, Raciais, Racionais: a grande frátria do rap na periferia de São

Paulo. São Paulo em Perspectiva, São Paulo, v. 13, n. 3. p. 95-106, set. 1999. https://doi.org/10.1590/S010288391999000300013

LUKÁCS, Georg. Teoria do romance. São Paulo: Duas Cidades: Editora 34, 2000.

NAPOLITANO, Marcos. Seguindo a canção. São Paulo Versão Digital, 2010. Disponivel em: https://www.academia.edu/3821530/SEGUINDO_A_CANCAO_digital. Acesso em: 13 fev. 2019.

NAVES, Rodrigo. A forma difícil. São Paulo: Companhia das Letras, 2011.

NOBRE, Marcos. 'Depois da 'formação'. Cultura e política da nova modernização. Revista piaui [s. l.], n.74, nov. 2012. Disponivel em: https://piaui.folha.uol.com.br/materia/ depois-da-formacao/. Acesso em: 20 out. 2019.

OLIVEIRA, Acauam Silvério de. O fim da canção? Tese (Doutorado) - Universidade de São Paulo, São Paulo, 2015.

OLIVEIRA, Francisco. Critica à razão dualista/O ornitorrinco. São Paulo: Boitempo, $2003 a$.

OLIVEIRA, Francisco. Programa Roda Viva, TV Cultura, $01 \mathrm{dez}$. 2003b. Disponivel em: https://www.youtube. com/watch?v=TFzPVVPLuqA. Acesso em: 03 mar. 2018.
ORTIZ, Renato. Imagens do Brasil. Sociedade e estado Brasilia, DF, v. 28, n. 3, p. 6og-633, dez. 2013. https://doi. org/10.1590/S0102-69922013000300008.

OTSUKA, Edu. Marcas da catástrofe: experiência urbana e indústria cultural em Rubem Fonseca, João Gilberto Noll e Chico Buarque. São Paulo: Nankin, 2001.

PASTA JR., José Antonio. O romance de Rosa: temas do Grande sertão e do Brasil. Novos Estudos CEBRAP, São Paulo, n. 55, p. 61-70, 1999.

PASTA JR., José Antonio. Prodígios de ambivalência: notas sobre "Viva o povo brasileiro". Novos Estudos CEBRAP, São Paulo, n. 64, p. 61-72, 2002.

PASTA JR., José Antonio. Uma conversa com José Antonio Pasta. Sinal de Menos, v. 4, p. 13-25, 2010 .

PASTA JR., José Antonio. Volubilidade e ideia fixa: o outro no romance brasileiro. Sinal de Menos, v. 4, p. 13-25, 2010b.

PASTA JR., José Antonio. Formação supressiva. Tese (Livre docência) - USP, São Paulo, 2011.

QUERIDO, Fabio Mascaro. Depois do colapso da modernização. Blog da Boitempo, 04 fev. 2013. Disponivel em: https://blogdaboitempo.com.br/2013/02/04/depois-do-colapso-da-modernizacao/. Acesso em: 24 jul. 2017.

RIDENTI, Marcelo Fantasma da revolução brasileira São Paulo: Editora UNESP, 1993

SCHWARZ, Roberto. O pai de familia e outros estudos. Rio de Janeiro: Paz e terra, 1978.

SCHWARZ, Roberto. Um mestre na periferia do capitalismo. São Paulo: Companhia das Letras, 2000.

SCHWARZ, Roberto. Que horas são? São Paulo: Cia das Letras, 2006.

SCHWARZ, Roberto. Desapareceu a perspectiva de um progresso que torne o pais decente. In: CARIELLO, R. Folha de S. Paulo, Ilustrada, São Paulo, 2007. Disponivel em: https://goo.gl/P7Tbil. Acesso em: 24 jan. 2019.

SCHWARZ, Roberto. Martinha versus Lucrécia. São Paulo: Cia. das Letras, 2012a.

SCHWARZ, Roberto. Ao vencedor as batatas. São Paulo: Duas cidades/Editora 34, 2012b.

SCHWARZ, Roberto. Sequências brasileiras: ensaios. São Paulo, Companhia das Letras, 2014

SPIVAK, Gayatri. Pode o subalterno falar? Belo Horizonte: Editora UFMG, 2010.

SZONDI, Peter. Teoria do drama moderno. São Paulo: Cosac Naify, 2011.

VELOSO, Caetano. Que caminho seguir na Música Popular Brasileira? Revista Civilização brasileira, [s. l.], ano I, n.7, maio 1966.

VELOSO, Caetano. Verdade tropical. São Paulo: Companhia das Letras, 1997.

WILLIAMS, Raymond. Marxismo e literatura. Rio de Janeiro: Zahar, 1979 


\section{REFERÊNCIAS DISCOGRÁFICAS}

CHICO BUARQUE. Carioca. Biscoito Fino, 2006

\section{Fernando Cambauva Breda}

Fernando Cambauva Breda. Mestrando do Programa de Pós-Graduação em Teoria e História Literária do Instituto de Estudos da Linguagem/UNICAMP. Desenvolve pesquisa sobre a "Tradição da Formação do Brasil" e suas implicações estéticas contemporâneas. Projeto de pesquisa orientado por Carlos Eduardo Ornelas Berriel, financiado por bolsa CAPES de 07/2018 a 10/2018 e pela FAPESP a partir de 11/2018 (processo 2018/12355-1). Graduado em Letras pela Universidade de São Paulo (USP). 